
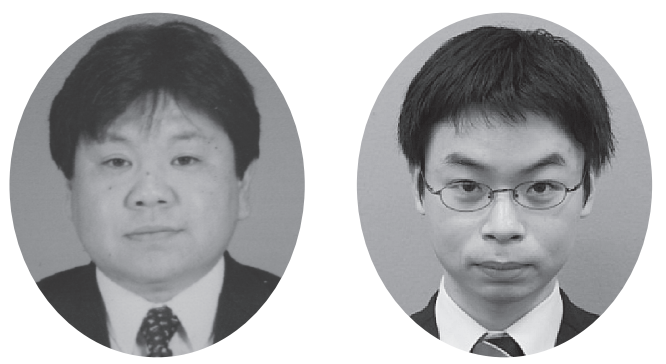

森 久史* .上東 直孝*

Journal of The Japan Institute of Light Metals, Vol. 66, No. 5 (2016), 226-232

(C) 2016 The Japan Institute of Light Metals

\title{
Feasibility of application of flame-retardant magnesium alloy to railway vehicles
}

\author{
Hisashi MORI* and Naotaka UEHIGASHI*
}

Keywords: vehicle, weight saving, flame-retardant magnesium alloy, strength, hollow shape material

\section{1. 緒言}

鉄道は自動車, 航空機と比較して $\mathrm{CO}_{2}$ 排出量の少ない輸送 手段であり，環境にやさしい輸送機関であると言えるが，さ らなる省力化の可能性について追求していく必要がある。

秦らは，鉄道技術のエネルギー消費について図1のように 分析し, 必要となる課題の設定を行っている ${ }^{1)}$ 。鉄道におけ るエネルギー消費量の大半は車両走行エネルギーが占めてお り, 省エネ化に対して車両の軽量化は重要な技術課題である ことが図 1 からも理解できる。

車両の軽量化は高速化やメンテナンス性の軽減などを目的 として検討されてきた。それには, 軽量材料の適用が最も有 効であり, 車両構体の強度ならびに剛性に配慮しながらアル ミニウム合金化，ステンレス化ならびに樹脂系複合材料の部 分適用などが進められてきた ${ }^{2) 〜 7}$ 。

今後の車両の軽量化においては，アルミニウム合金，ステ ンレスおよび樹脂系複合材料よりも比強度の高い難燃性マグ

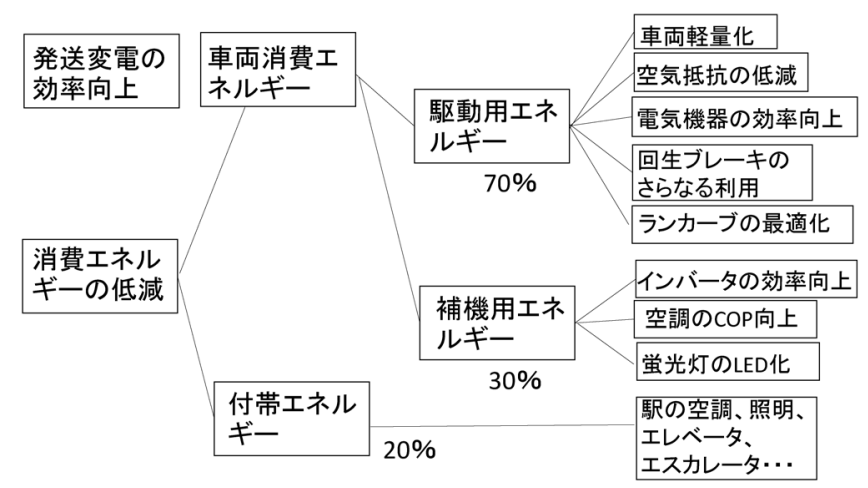

図 1 鉄道技術における省エネルギー化の課題 ${ }^{1)}$
ネシウム合金の適用が考えられる ${ }^{8)}$ 。難燃性マグネシウム合 金は，カルシウムを添加して発火温度を上昇させた合金であ り，難燃性を有し，さらに高い比強度を維持している ${ }^{9)} 。$

たとえば，単純な板材を仮定して強度および弾性率に基づ く軽量化効果を検討すると，アルミニウム合金に比べて強度 重視設計では約 3 割, 弾性率設計では約 2 割の軽量化が見込 める試算ができる。しかし，難燃性マグネシウム合金は研究 開発段階の材料であり, さらにマグネシウム合金が一次強度 部材として適用された例がない。そのため，難燃性マグネシ ウム合金を適用するための車両強度および剛性の検討を始め る以前に, 今後, 車両を製造してゆくための基本技術として, 素材, 加工, 溶接に関する各技術の確立が必要である。また, 設計のための強度, 疲労強度等の検討も必要になる。

本稿ではまず軽量化のニーズを示し, 続いて車両構体に必 要となる事項について整理する。その後, 難燃性マグネシウ ム合金の適用に対する必要技術を示し, 研究動向を簡単に紹 介する。

\section{2. 鉄道車両の軽量化}

\section{1 鉄道車両の軽量化の必要性}

鉄道車両は電動機の出力を車輪に伝達し, 走行抵抗等の抵 抗に打ち勝って加速して走行する。走行抵抗は車輪とレール 間の摩擦抵抗に影響を受け, 列車重量に比例する。したがっ て, 列車重量を軽くすることによって, 走行エネルギーを減 少させることができる。特に大きなエネルギーを必要とする 加速時に軽量化の効果が認められ, 軽量化率が走行抵抗の減 少となって現れるようになり, 駅間距離が短く, 頻繁に発・ 停止を繰り返す都市型の高速鉄道ではその効果が大きい。ま た，省エネルギー化のほか，加速に対して良好な効果を示す

*公益財団法人鉄道総合技術研究所 材料技術研究部（干185-8540 東京都国分寺市光町 2-8-38） Materials Technology Division, Railway Technical Research Institute (2-8-38 Hikari-cyo, Kokubunji-shi, Tokyo 185-8540) E-mail: mori.hisashi.47@rtri.or.jp 受付日：平成27年11月12日＼cjkstart受理日：平成28年2月23日 
ために高加速度運転が可能になり，運転速度を向上すること ができる。その結果，高速化による到達時間の短縮化によっ て, 輸送サービスの向上が図れる。さらに, 軽量化は, 摩耗 部品の寿命を延ばすほか，輪重が軽くなることで軌道破壊が 減少するために，車両や軌道の保守費が低減するなど，経済 上に対しても波及効果が増加する。その一方，軽量材を使用 することによる初期コストや補修費用の増加, 剛性, 遮音性 の低下による乗り心地や車内騒音の増大などのデメリットも 考えられる。

これらのことから車両の軽量化は, メリットおよびデメ リットを分析して経済的な効果などを考慮しつつ検討する必 要があり，鉄道事業者側における重要な技術課題として位置 づけられている。

\section{2 鉄道車両に必要な特性}

2.2.1 車両用材料に必要な特性

鉄道車両に適用する材料は, 無害であり, 比較的入手しや すいこと, コストが安価であること, 難燃・不燃であること, そして安全性, 快適性（剛性，遮音性，制振性），耐久性（強 度, 耐力, 疲労特性, 摩耗特性, 耐食性) が常に求められる。 また，材料自体の加工性（押出性（薄肉・中空）, 成形性（圧 延・プレス)）や溶接性に優れることが必要である。また, 最近ではリサイクル性も考慮されるようになってきている。

\section{2 .2 車両構体に必要な特性}

鉄道車両の構体を考えるには，様々な条件から受ける荷重 に対する許容応力を明らかにする必要がある。また，車体各 部の上記した強度が十分に許容範囲内であっても剛性が低い 場合には走行中に車輪やレールに起因する振動を受けたとき に車体の振動が大きくなり乗り心地に影響を及ぼす。した がって剛性も強度とともに重要な指標となる。

(a) 車体が受ける強度

車体構体が受ける強度には, 静的荷重および動的荷重があ る。静的荷重には垂直荷重（乗客および機器を含めた荷重） および車端荷重（ブレーキ時において連接している車両から 受ける荷重) がある。また動的荷重としては疲労荷重がある。 強度設計ではこれらの荷重条件を把握し, JIS E 7103 鉄道車 両一旅客車一車体設計通則に従って行われる。

(b) 車体の剛性

車体の剛性としては，相当曲げ剛性と相当ねじり剛性があ る。相当曲げ剛性は，車体の曲げに対するたわみにくさであ り，相当ねじり剛性とは，ねじりに対する変形しにくさであ る。強度とは異なり，剛性について規定值はないが乗り心地 を悪くしないために高く設けることが望ましい。車体全体の 剛性の求め方についても, JIS E 7103 鉄道車両-旅客車-車体 設計通則に従って計算される。

\section{3 剛性確保の課題}

軽量材料は縦弾性率が低いために剛性の確保が課題とな る。剛性を上げるには構造部材自体の断面積をなるべく小さ くしながら, 面積要素に対する重心軸からの距離を有効にと り，断面二次モーメントを大きくするといった配慮が必要に なる。この手法には，押出形材の有効利用が考えられる。

たとえば，現在，アルミニウム合金車両では図2に示すよ うな中空形材を使用した構造（ダブルスキン構造）とし，剛 性の確保が行われている ${ }^{10)}$ 。

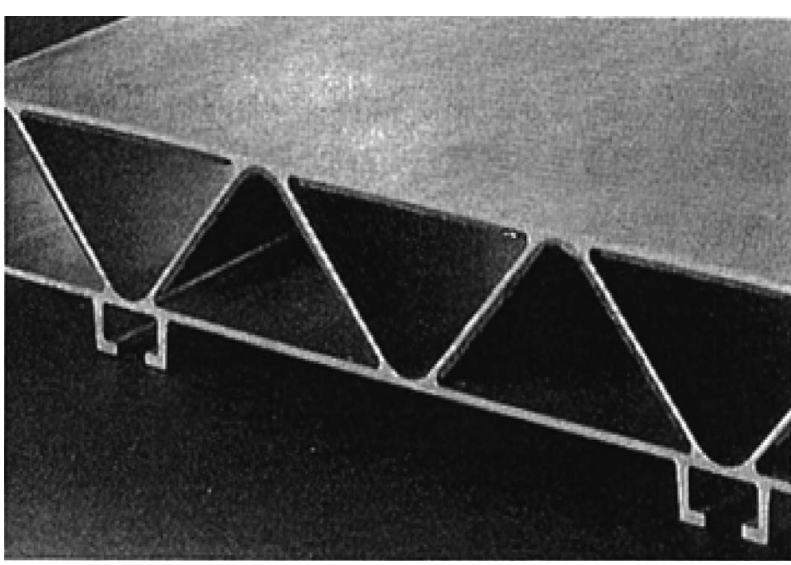

図2 車両用の中空形材の外観 ${ }^{10}$

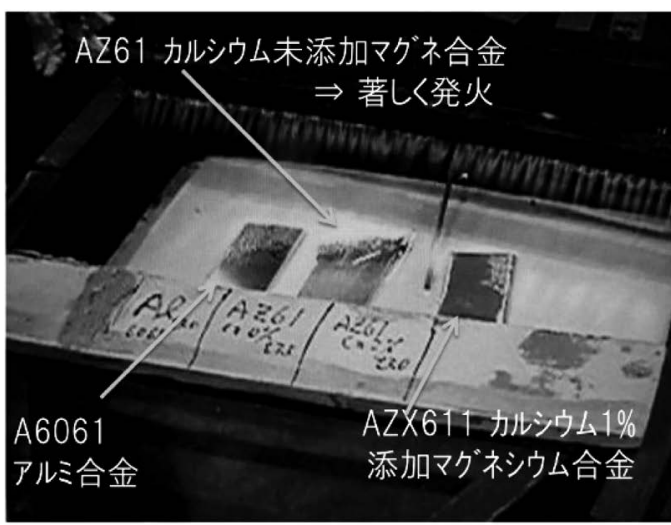

AZ61:Mg-6Al-Zn alloy AZX611:Mg-6Al-Zn-Ca alloy

図3 マグネシウム合金（AZ61），難然性マグネシウム 合金（AZX611），アルミニウム合金（A6061）圧 延材の燃焼試験の状況

\section{3. 難燃性マグネシウム合金の車両への適用に対す る必要技術}

難燃性マグネシウム合金は, カルシウムをマグネシウム合 金に添加して発火温度を上昇させた合金である。一般の AZ 合金のような汎用マグネシウム合金ではなく，材料特性や溶 接, 加工，表面処理などのさまざまな研究開発が行われてい る。特に，難燃性マグネシウム合金の車両への適用を考える にあたり，主に下記の技術が求められる。

・素材の難燃性および材質の確認

·機械的性質, 加工性, 溶接性等の諸特性の把握

・部材作製技術（幅広材，長尺材）の確立

・最適な溶接・接合技術の提示

・溶接および接合部の疲労を含めた信頼性の確保

・表面処理および塗装技術の確立

・材料のコストダウンおよび生産性の確立

・マグネシウム合金適用の構造技術

\section{4. 難燃性マグネシウム合金の技術動向}

\section{1 素材の難燃性および材質の確認}

マグネシウム合金の難然性化に対してカルシウムの添加が 有効であるとされている ${ }^{9)}$ 。図3に Mg-6Al-1Zn合金 (AZ61) にカルシウムを添加した合金（AZX611）と比較に用いたア 
Casting direction

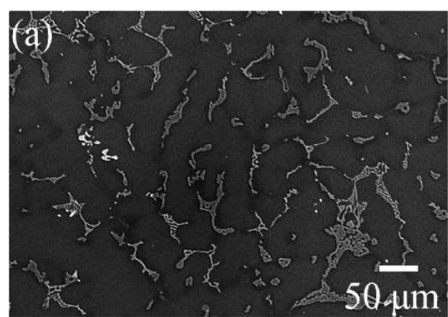

Rolling direction $\Leftrightarrow$

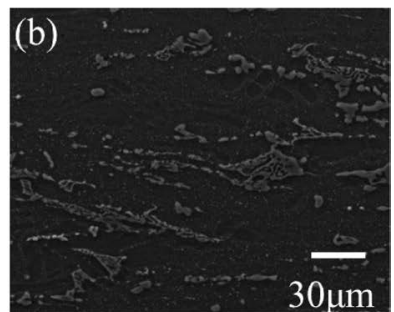

図4 難燃性マグネシウム合金 $(\mathrm{Mg}-6 \mathrm{Al}-1 \mathrm{Zn}-1 \mathrm{Ca}$ 合 金：AZX611）の（a）鋳造材および（b）圧延材 の走査型電子顕微鏡 (SEM) 像

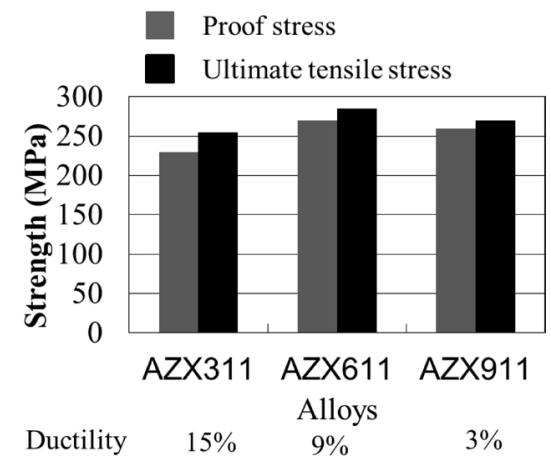

図 5 難燃性マグネシウム合金（Mg-Al-Zn-Ca 合金 $\mathrm{AZX)}$ 圧延材のアルミニウム添加量が耐力, 引張 強さおよび伸びに及ぼす影響

ルミニウム合金（A6N01）材をバーナで加熱し，発火性の評 価を行った結果を示す。AZ61では融点の約半分の温度で著 しい発火を認めたが，AZX611では発火が認められずに溶融 した。これはA6N01 と同じ傾向が認められた。このような カルシウムの添加により発火が抑制された理由としては, カ ルシウムの添加による酸化カルシウム $(\mathrm{CaO})$ の生成が燃焼 に対するバリアとして作用したと考えられる ${ }^{9), 11}$ 。

今後は難燃性を定量的に評価するためのパラメータの設定 や試験方法, カルシウムの添加量などの検討が必要になると 考えられる。

図4の（a）に難燃性マグネシウム合金の鋳造材，（b）に その圧延材の金属組織を示す。鋳造材には $\alpha$ 固溶体のデンド ライト境界にアルミニウムとカルシウムとの金属間化合物が

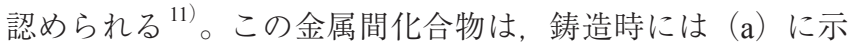
すようにネットワーク状で認められたが，圧延加工を行うこ とにより，（b）に示すように圧延により粉砕されて圧延方向 に認められるようになる。このことで，金属間化合物は塑性 加工によって晶出形態の制御が可能であると考えられる。

\section{2 特性の把握}

図 5 に $\mathrm{Mg}-3 \mathrm{Al}-1 \mathrm{Zn}-1 \mathrm{Ca}(\mathrm{AZX} 311), \mathrm{Mg}-6 \mathrm{Al}-1 \mathrm{Zn}-1 \mathrm{Ca}$ (AZX611), Mg-9A1-1Zn-1Ca (AZX911) の耐力, 引張強さ および伸びを示す。図に示すようにアルミニウム量とともに 耐力, 引張強さが増加し, アルミニウムによる固溶強化の作 用が確認される。しかし, 固溶強化には限度があり, アルミ ニウム量の増加とともに伸びが低下する。これは, アルミニ ウムとカルシウムとの化合物量が増加し，ボイドやき裂生成 点が増加するためであると考えられる ${ }^{11)}$ 。

今後の材料設計を考えるうえで，強度や伸びと金属組織と

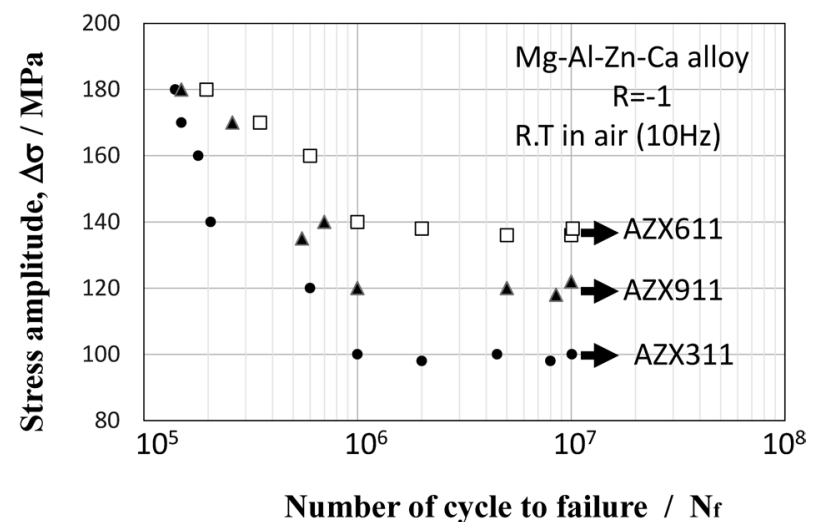

図6 難燃性マグネシウム合金（AZX）圧延材の平面曲 げ疲労試験時の $S-N$ 線図

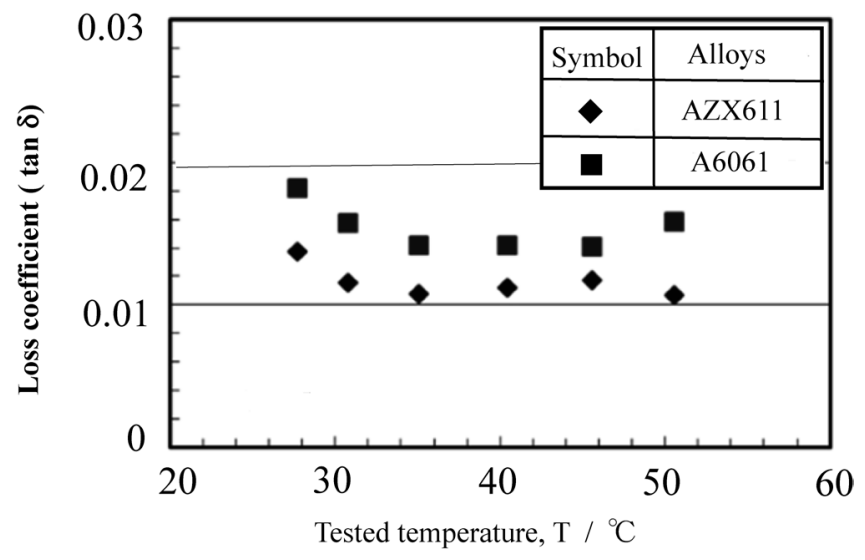

図7 難燃性マグネシウム合金 (AZX611) 圧延材の損 失係数の温度依存性

の関係の定量的な把握が必要であると考えられる。

一方, 疲労強度についても, 耐力および引張強さと類似 する傾向が認められ，比較した中で, AZX611>AZX911> AZX311であった（図6）。AZX611がAZX911に比べて疲労 強度が高い理由としては, AZX611では強度のほかに伸びの 影響もあると考えられるが，このような疲労破壊メカニズム を含めた考察は今後の課題としたい。

マグネシウム合金の利点として高い比強度特性を示すほか に減衰能に富むことがあげられる。難燃性マグネシウム合金 の減衰能を損失係数 $(\tan \delta)$ によって測定した結果では, 図 7 に示すように難燃性マグネシウム合金の損失係数がアルミ ニウム合金（A6061）と同等または若干下回る傾向が認めら れた。マグネシウム合金の減衰能は双晶型で認められるとの 報告がある ${ }^{12)}$

難燃性マグネシウム合金では金属組織中にアルミニウムと カルシウムとの晶出物が認められることや加工による結晶粒 の微細化によって双晶変形が妨げられることなどにより, 純 マグネシウムで認められるような高減衰能を示さなかったと 考えられる。

一方，マグネシウム合金は結晶が $\mathrm{HCP}$ 構造を有するため, 塑性変形時に活動するすべり系が少なく，加工性が悪い ${ }^{13)}$ しかし，難燃性マグネシウム合金においても，流動応力に対 する温度およびひずみ速度の影響が認められ，温度上昇，ひ ずみ速度の低下とともに変形抵抗が減じて加工しやすくなる 


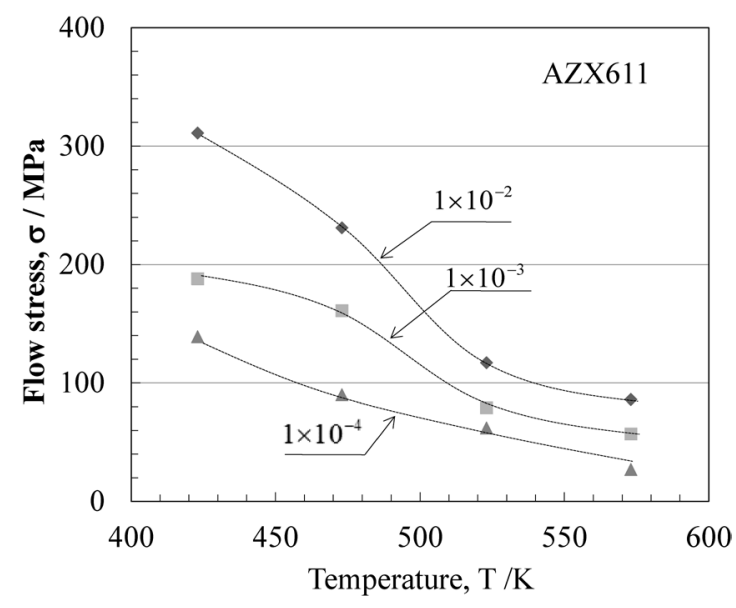

図8 難燃性マグネシウム合金 (AZX611) 圧延材の流 動応力に及ぼす温度およびひずみ速度の影響

\begin{tabular}{|c|c|c|c|c|c|}
\hline$\dot{\varepsilon} / \mathrm{s}^{-1}$ & \multicolumn{5}{|c|}{$2.7 \times 10^{-1}$} \\
\hline $\mathrm{T}_{\text {C.C. }} / \mathrm{K}$ & 293 & 373 & 423 & 473 & 523 \\
\hline $\mathrm{D}_{0} / \mathrm{mm}$ & 36.0 & 32.6 & 28.1 & 28.1 & 27.1 \\
\hline $\mathrm{H}_{0} / \mathrm{mm}$ & 1.8 & 8.5 & 14.4 & 15.5 & 16.1 \\
\hline $\begin{array}{l}\text { Specimens } \\
\text { configuration }\end{array}$ & & & & & \\
\hline
\end{tabular}

図9 難燃性マグネシウム合金 (AZX611) 圧延材のコ ニカルカップ試験の結果

可能性がある（図8）。たとえば, 深絞り性の評価に対して 福井式コニカルカップ試験によって調べた結果, 図 9 に示す ように深絞り性は温度増加とともに良好となる結果が得られ ている。これらのことから，難燃性マグネシウム合金の加工 は室温では著しく困難であるが，高温・低ひずみ速度化にな るほど良好になることが確認された。

\section{3 部材作製技術の確立}

鉄道車両の製造にはさまざまな形状の部材が用いられてい る。部材には板材と押出材が使われているが, 現在ではコス トや一体性が考慮されて押出材が主として使用されている。

特に難燃性マグネシウム合金の縦弾性率（約 $42 \mathrm{GPa}$ ) はア ルミニウム合金のそれ（約 $70 \mathrm{GPa} ）$ と比較して低いため, 剛 性の低下が課題になり，それに対して図10に示すような中 空形材やリブ付き形材, チャンネル断面材を押出加工によっ て作製した材料の適用が見込まれる。

押出加工は, 材料の変形や最終形状に強く依存し, 製品作 製にあたる押出しのしやすさの傾向を知る一つの目安とし て（1）式に示す難易度ファクタがあげられる ${ }^{14)}$ 。

難易度ファクタ

$=$ 形材断面の全周長 $(\mathrm{mm}) /$ 形材の単重 $(\mathrm{kg} / \mathrm{m})$

難易度ファクタが小さい形材ほど製造が容易で寸法精度の よい押出製品を得やすい。たとえば，アルミニウム合金と同 一寸法のマグネシウム合金製中空形材を作製すると考えた 際，マグネシウム合金では，アルミニウム合金よりも軽いこ とから難易度ファクタが大きくなる。そのため, マグネシウ ム合金製の中空形材の作製はアルミニウム合金よりも難易度

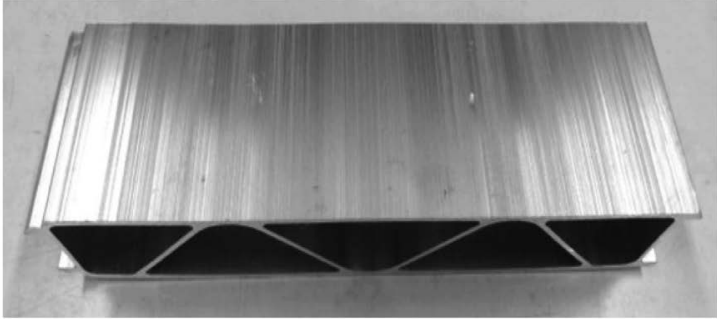

中空押出形材 (Mg-6Al-Zn-Ca合金 : AZX611)

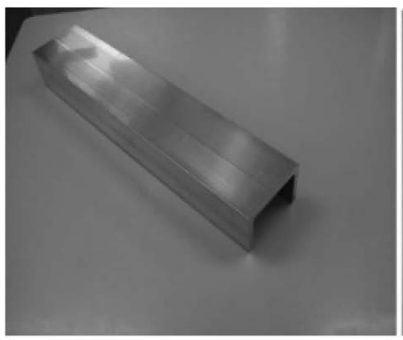

(コ形断面材)

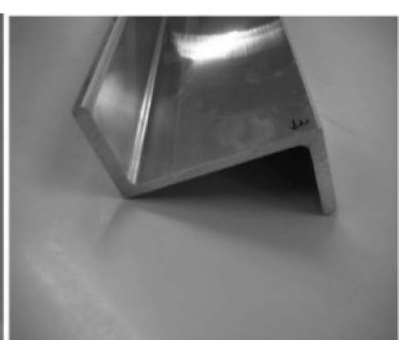

(Z形断面材)
（チャンネル断面材（Mg-9A1-Zn-2Ca合金：AZX912））

図 10 難燃性マグネシウム合金製の押出形材の試作例
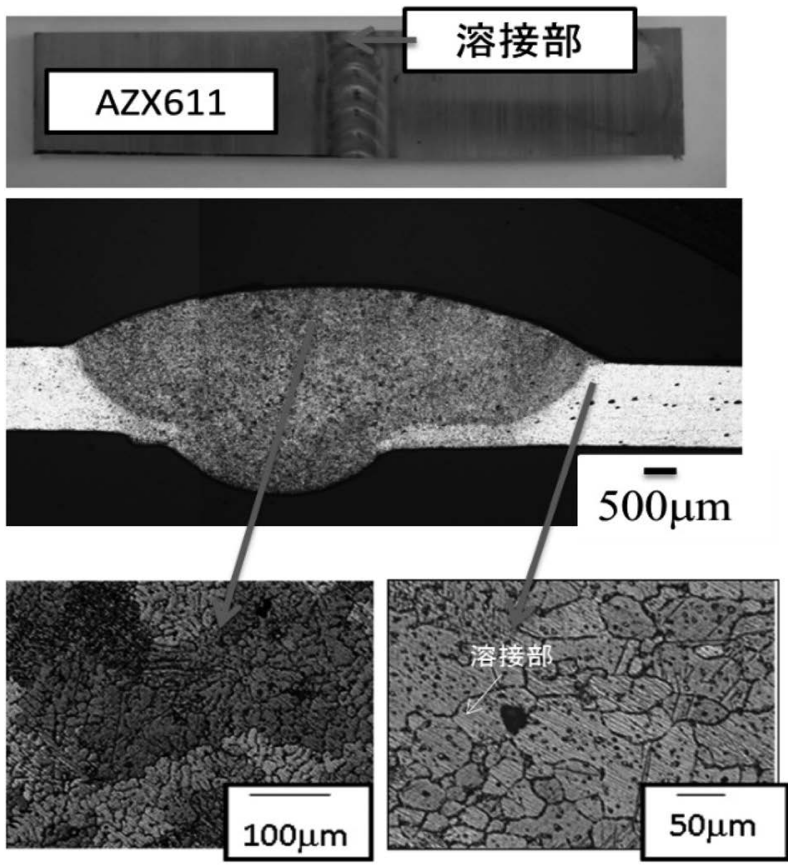

ビード部

熱影響部

図 11 難燃性マグネシウム合金 (AZX611) のTIG 溶接 の結果および溶接部の断面マクロ組織およびミ クロ組織。溶接棒もAZX611を使用

が高いと考えられる。

難燃性マグネシウム合金の形材の試作においても，図2の ような中空形材の試作において，薄肉部が厚肉部よりスト レッチ効果を受けやすいため, 薄肉部の方向に反りが生じや すく曲がりなどが生じた。そこで，押出加工時におけるメ夕 ルフロー等の考慮や押出しやすい断面形状へと変更すること によって, 図 10 に示すような中空形材, コ形およびZ形断 面のチャンネル材の作製を可能にした。現在では長さが数 $\mathrm{m}$ 程度のモデル材に留まっているが, 実用化においては, 均一 形状の寸法・肉厚を有する $25 \mathrm{~m}$ 長の長尺・幅広材の作製が 

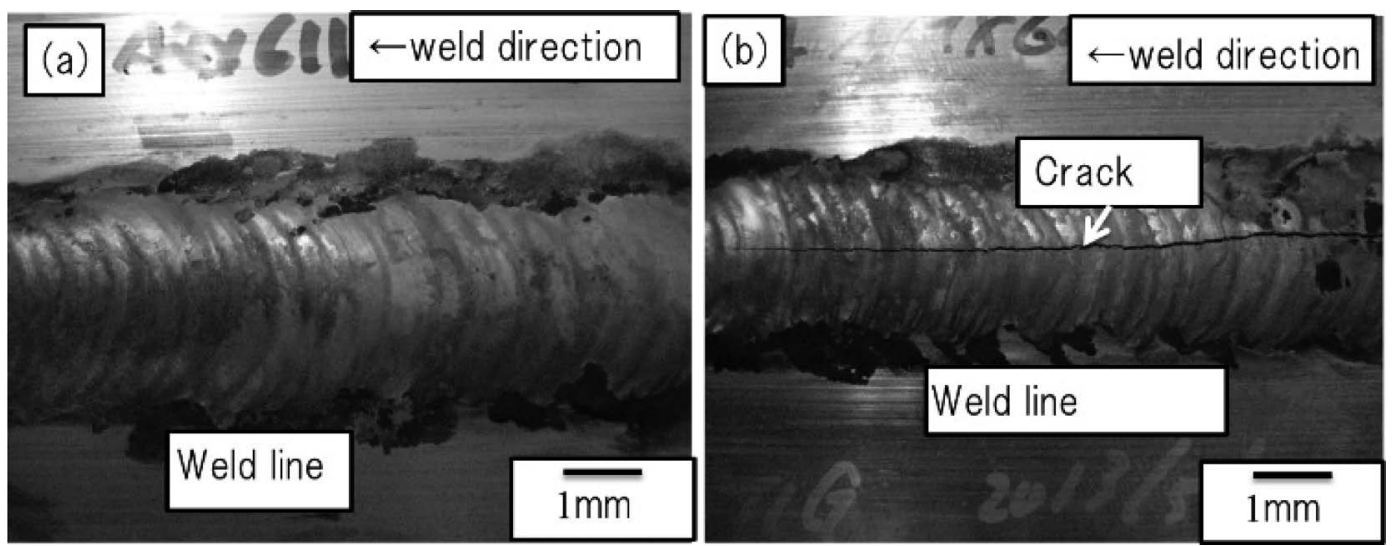

図 12 健全条件（a）および電流過剰条件（b）でTIG 溶接を行ったときの難燃性マグネシウム合金（AZX611）圧延材の 溶接ビード部の外観

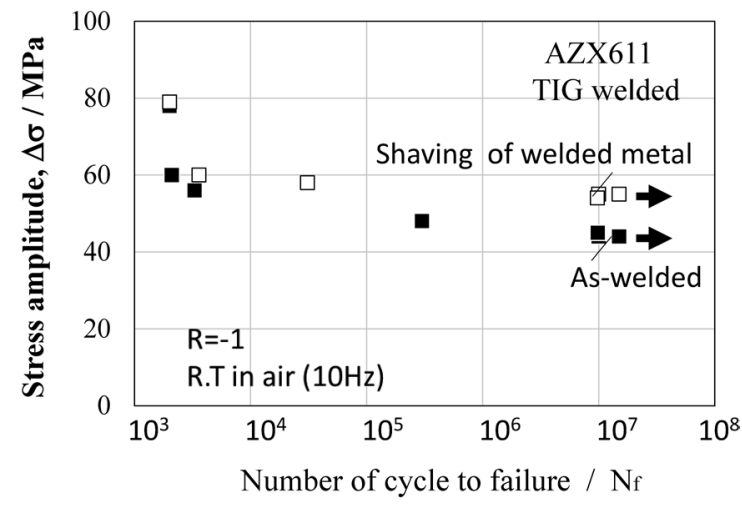

図 13 難燃性マグネシウム合金 (AZX611) 圧延材の TIG 溶接材の平面曲げ疲労試験で得られた $S-N$ 線 図

\section{必要になる。}

このような長尺材の加工では, 押出後の後行程での形状矯 正を行うよりは，むしろ押出時に変形の少ない精度の良好な ものが必要である。それには安定なメタルフローを得るほ か, 形状崩れ改善が求められる。特に屋根のような曲面を有 する薄肉形材の作製では熱間状態で自重により曲面部が扁平 化するため，局部形状保持を考える必要があることが明らか にされている ${ }^{15)}$

\section{4 溶接・接合技術の検討}

4. 4.1 アーク溶接の試み

現在の車両は全溶接組立方法で作製されている。

製造に用いられている溶接手法は TIG 溶接，MIG 溶接の アーク溶接や摩擦攪拌接合（FSW）が適用されている。

難燃性マグネシウム合金の圧延板材に対する TIG 溶接の施 工の結果，溶接施工中には発火も認められず，図 11 に示す ように，良好な溶接部が得られている。また，断面組織を光 学顕微鏡で観察した結果, ビード部には鋳造組織が認めら れ，熱影響部には粗大結晶粒が認められた。条件が適切であ れば，難燃性マグネシウム合金への TIG 溶接も可能であるこ とを確認した。ただし, 溶接電流および電圧が適切でない場 合には図12に示すような高温割れが発生する。

溶接部の断面ビッカース硬さは，母材で $50 \mathrm{Hv}$, 凝固部で $45 \mathrm{Hv}$ ，熱影響部で $38 \mathrm{Hv}$ であり，多少のばらつきがあるもの の，熱影響部において軟化が認められている。

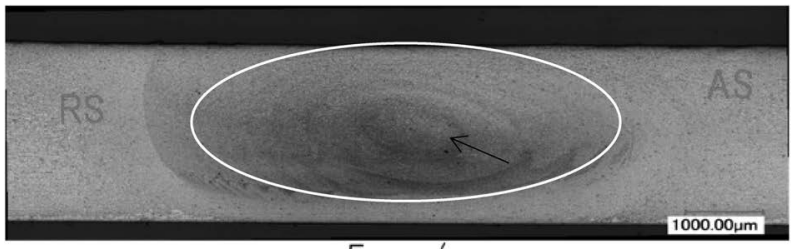

$5 \mathrm{~mm} / \mathrm{s}$

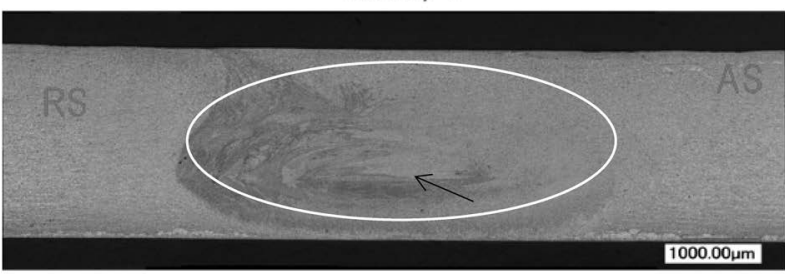

$10 \mathrm{~mm} / \mathrm{s}$

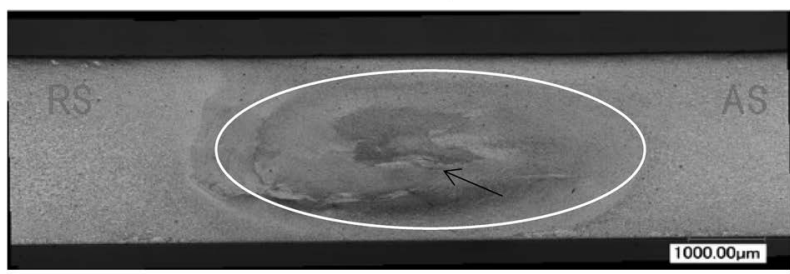

$15 \mathrm{~mm} / \mathrm{s}$

図 14 難燃性マグネシウム合金（AZX611）の圧延板材 にツール送り速度を $5,10,15 \mathrm{~mm} / \mathrm{s}$ でFSW した断 面のマクロ組織観察結果。図中矢印は流動層を 示している

TIG 溶接材の引張試験の結果, 破断が熱影響部で認めら れ, 継手効率は 70\%程度であることを確認している。 TIG 溶 接材の疲労強度は図6 拈よび図 13 より, 母材と比較して低 下する。これはアルミニウムとカルシウムとの晶出物が欠陷 として作用すると考えれば, 晶出物の含有率の高い難燃性マ グネシウム合金では, 疲労強度が低下することが推察され る。また, 疲労強度は余盛有無の影響を受ける（図 13）。こ れは止端部における応力集中がひとつの原因になったためと 考えられる。

\section{4. 2 FSW 適用の試み}

鉄道車両のような大型構造物へのアーク溶接では, ひずみ の問題が大きく, 除去に多大な工程を要している ${ }^{4)}$ 。特に熱 膨張が鉄よりも大きいマグネシウム合金では溶接時のひずみ の問題が極めて重要になる。そこで近年, ひずみの発生が少 


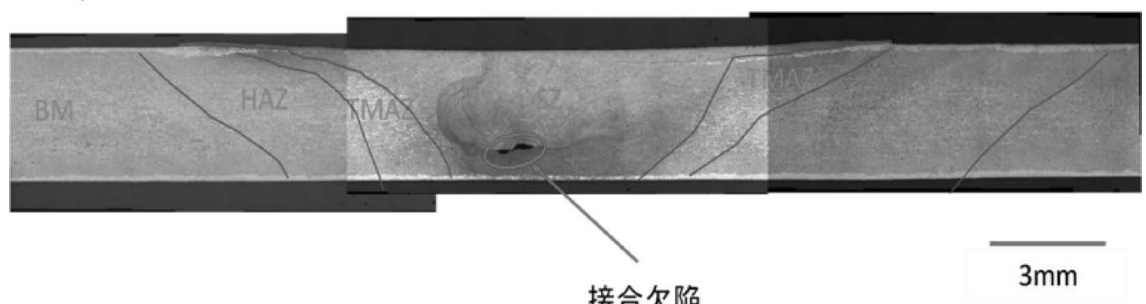

図 15 ツール送り速度を $20 \mathrm{~mm} / \mathrm{s}$ でFSW した難燃性マグネシウム合金（AZX611）の圧延板材の断面のマクロ組織観察結 果 (SZ：攪拌部, TMAZ：熱塑性加工部, HAZ：熱影響部, BM：母材）
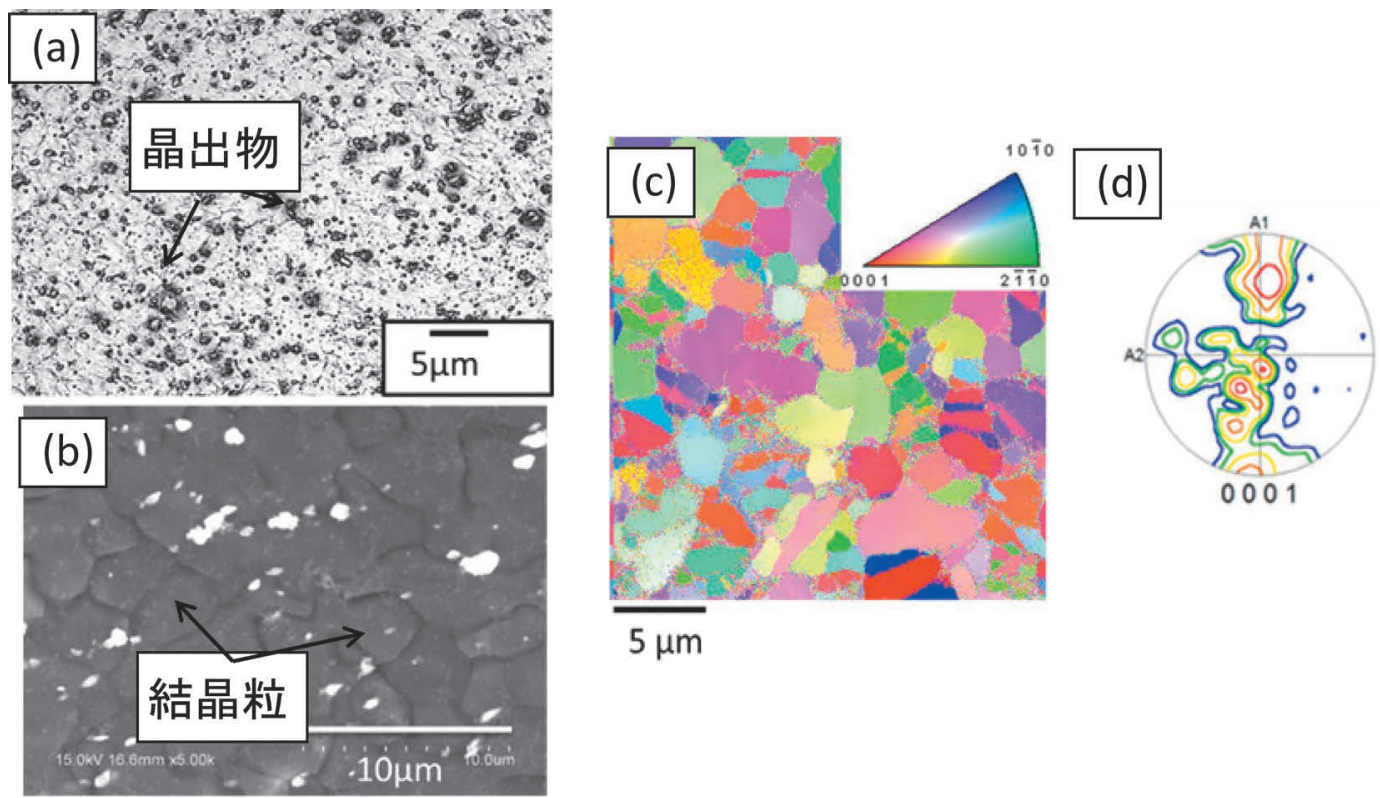

図 16 難燃性マグネシウム合金（AZX611）圧延材におけるFSW 接合材の攪拌部（SZ部）に認められた断面金属組織。(a) 光学顕微鏡によるSZ部の金属組織，（b）SZ部のSEM像，（c）EBSD 方位解析のIQマップ，（d）（0001）面極点図

ない, 軽金属の最良な溶接手法としてFSWの適用が注目さ れており，鉄道車両の製造にも適用されている ${ }^{16)} 。$

ツールの送り速度を制御して難燃性マグネシウム合金板材 にFSWを行い, 接合部断面マクロ組織を示したのが図 14で ある。

接合部中心には円状のような金属組織の変化が認められ る。これはオニオンリングと呼ばれ，金属組織の塑性流動に よる結果で形成される, FSW材断面に特有の金属組織であ る ${ }^{17)}$ 。オニオンリング状組織変化において，送り速度が増 加するに従い, 円状の流動組織が不明瞭になる傾向が認めら れた。送り速度を $20 \mathrm{~mm} / \mathrm{s}$ でFSW した時の断面マクロ組織観 察結果を図15に示す。送り速度が大きくなると接合部にボ イド状の欠陥の発生を認めた。送り速度は摩擦熱に影響を及 ぼすと考えられる。FSWでの摩擦熱量については, FSWの 施工パラメータに対して（2)式で与えられる ${ }^{18)}$ 。

$$
Q=\frac{3}{4 \pi} \cdot R^{3} \cdot P \cdot N \cdot \frac{\mu}{V}
$$

ここで, $R$ はショルダ径, $P$ はツール荷重, $N$ はツール回 転数, $V$ は送り速度, $\mu$ は摩擦係数である。 $R, P, N, \mu$ は一定 であることから送り速度が増加すると熱量が下がる傾向にあ る。このことから，欠陷は入熱不足により発生したものと推 定される。このように, 健全な溶接部を得るためには最適な
条件による施工が重要であるが, 難燃性マグネシウム合金の FSW 条件はアルミニウム合金の6000系と比較して条件の幅 が狭いことを確認している。

図16にFSW 接合材に認められた接合部断面における攪汼 層 (SZ部) の金属組織を示す。SZ部では晶出物が微細にな り, 結晶粒も微細な状態で認められた。

母材の結晶粒径が約 30〜 40 $\mu \mathrm{m}$ であり, SZ 部の結晶粒径が 1〜 $10 \mu \mathrm{m}$ 程度である。このことから, SZ部に認められた結 晶粒の微細化は, FSW 時の機械的分断や動的再結晶化によ るものと考えられる。また, SZ部に認められるその他の金 属組織の特徵として, 結晶粒の多くが主に 0001 面に配列し た状態にあることがあげられる。

図17に接合材の断面硬さ分布を示す。最も結晶粒が微細 化した中心付近では著しい硬化が認められ, 結晶粒微細化に よる硬化が確認された。FSW接合材の引張試験を行った結 果, 破断強さが, ほぼ母材と同じ強度を示し, 継手効率が 90\%以上を示すことを確認した。アーク溶接では熱影響部の 結晶粒粗大化に伴い軟化するのに対し, FSWでは, 結晶粒 の微細化および集合組織の形成により強化するため, 難燃 性マグネシウム合金の溶接に対してもFSWが有効であるこ とを確認した ${ }^{17)}$, 19)。今後は適する条件を明確にし, さらに 図 14 に認められるような欠陥検出の非破壊検査方法の確立, 形材溶接用継手の工夫, 継手の疲労強度の確認などの開発・ 


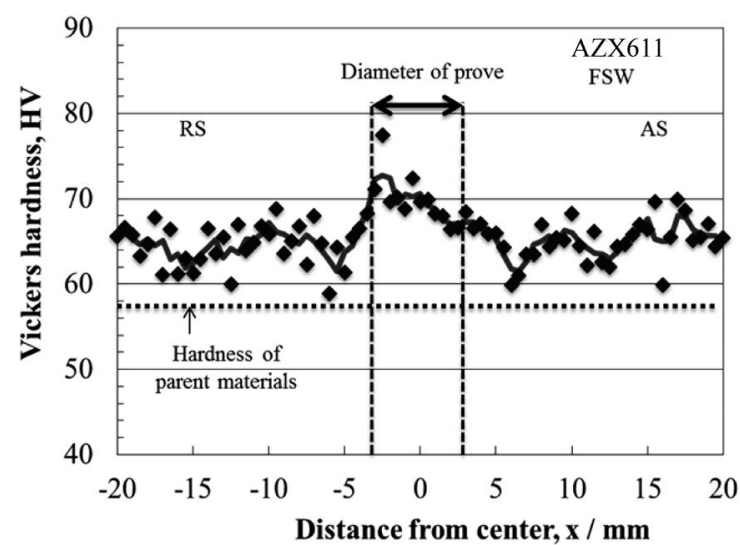

図17 難燃性マグネシウム合金（AZX611）圧延板材の FSW 接合材の断面硬さ分布

検証が必要であると考えられる。

\section{5. 結言}

車両の軽量化に対する難燃性マグネシウム合金の適用可能 性を調べるために，難燃性マグネシウム合金の材料，材料特 性，加工技術，溶接・接合手法に関する基礎的な動向を示し た。車両用材料としての適用可能性は十分にあると考えら れ，加工や溶接についても，技術的な見通しはあるものと考 えられる。しかし，実用化に対しては，表面処理技術等を含 めてさらに研究開発の活性化が強く望まれる。

謝 辞

本研究をまとめるにあたり，適切な助言をくださいまし
た, 長岡技術科学大学 鎌土教授, 元 千葉工業大学 船見 教授，JR東日本 藤野様，JR西日本 真下様に心より感謝 申し上げます。また，研究にご協力いただきました，三協立 山株式会社三協マテリアル社, 不二ライトメタル株式会社, 権田金属工業株式会社, 木ノ下伸線株式会社, 株式会社総合 車両製作所, 茨城県工業技術センターの各位に対しまして心 より厚くお礼申し上げます。

\section{参 考 文 献}

1) 秦 広: RRR, 69 (2012), 4-7.

2）松澤 浩：鉄と鋼，69（1983），1967-1971.

3）馬場義雄, 西村嘉彦：軽金属, 33 (1983), 618-631.

4) 塔本 徹, 阪口 章：溶接学会誌，40（1971）， 506-522.

5) 鈴木康文：鉄と鋼，79（1993）, N568-N575.

6) 鈴木康文：軽金属，60（2010），565-570.

7) 水田明能, 木村敏宣 : まてりあ, 43 (2004), 392-395.

8) 森 久史, 藤野謙司, 栗田 健, 千野靖正, 齋藤尚文, 野田雅 史，駒井 浩，小原 久：まてりあ，52（2013），484-490.

9) 秋山 茂, 上野英俊, 坂本 満, 平井寿敏, 北原 晃: まてり あ, 39 (2000)，72-74

10）軽金属協会：軽金属車両委員会報告書, No. 6 （1999），23-24.

11）秋山 茂: 鋳物, 66 (1994), 38-42.

12）杉本孝一：日本金属学会会報，10（1971），44-46.

13）金子純一, 菅又 信：軽金属, 54 (2004)，484-492.

14) 田中 浩, 叶 秀作：軽金属, 21 (1971), 551-563.

15）軽金属協会：軽金属車両委員会報告書, No. 4（1984），127134.

16）森 久史, 野田雅史, 富永誉也：軽金属，57（2007），506-510.

17）柴柳敏哉：軽金属, 57 (2007), 416-423.

18）岡村久宣, 青田欣也, 高井英夫, 江角昌邦：溶接学会誌, 72 (2003), 436-444.

19) 山本尚嗣, 廖 金孫, 中田一博：日本金属学会誌, 75 (2011), 91-96. 